\title{
Antibacterial Copper-Doped Calcium Phosphate Glasses for Bone Tissue Regeneration
}

Farzad Foroutan, ${ }^{\dagger} \ddagger$ Jamie McGuire, ${ }^{\dagger,}$ Priyanka Gupta, ${ }^{\S}$ Athanasios Nikolaou, ${ }^{\ddagger}$ Benjamin A. Kyffin, ${ }^{\ddagger}$ Nicole L. Kelly, ${ }^{\perp}$ John V. Hanna, ${ }^{\perp}{ }^{\circledR}$ Jorge Gutierrez-Merino," Jonathan C. Knowles, $, \square, \bigcirc, \triangle \odot$ Song-Yi Baek, Eirini Velliou, ${ }^{\S}$ and Daniela Carta*,*(i)

${ }^{\ddagger}$ Department of Chemistry, ${ }^{\S}$ Department of Chemical and Process Engineering, Bioprocess and Biochemical Engineering group (BioProChem), "School of Biosciences and Medicine, University of Surrey, Guildford GU2 7XH, United Kingdom

${ }^{\perp}$ Department of Physics, University of Warwick, Coventry CV4 7AL, United Kingdom

${ }^{\#}$ Division of Biomaterials and Tissue Engineering, Eastman Dental Institute, University College London, 256 Gray's Inn Road, London WC1X 8LD, United Kingdom

$\square_{\text {The Discoveries Centre for Regenerative and Precision Medicine, University College London, London WC1E 6BT, United }}$ Kingdom

ODepartment of Nanobiomedical Science \& BK21 PLUS NBM Global Research Center for Regenerative Medicine, and $\triangle_{\text {UCL }}$ Eastman-Korea Dental Medicine Innovation Centre, Dankook University, Cheonan 31114, Republic of Korea

Supporting Information

ABSTRACT: Calcium phosphate glasses are a promising new generation of biomaterials that can simultaneously induce tissue regeneration and controlled release of therapeutic molecules. In this work, novel calcium phosphate glasses containing $0,2,4$, and $6 \mathrm{~mol} \% \mathrm{Cu}^{2+}$ were synthesized via room temperature precipitation reaction in aqueous solution. The effect of $\mathrm{Cu}^{2+}$ addition on the glass properties and structure was investigated using thermal analysis, ${ }^{31} \mathrm{P}$ solidstate MAS NMR, Raman spectroscopy, and X-ray diffraction. All glasses crystallize at temperature $>500{ }^{\circ} \mathrm{C}$ and are mainly
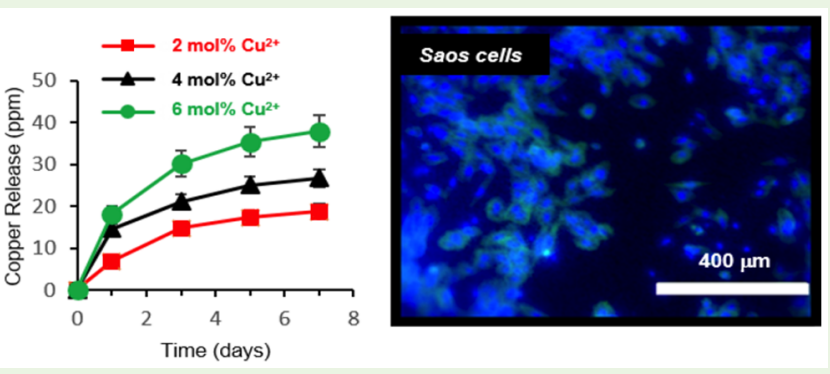
formed by $\mathrm{Q}^{1}$ groups. The release of $\mathrm{P}, \mathrm{Ca}$, and $\mathrm{Cu}$ in solution over time was monitored via inductively coupled plasma-optical emission spectroscopy. It was found that with increasing $\mathrm{Cu}$ content, the amount of $\mathrm{P}$ and $\mathrm{Ca}$ released decreases whereas the amount of $\mathrm{Cu}$ released increases. The effect of $\mathrm{Cu}^{2+}$ release on the antibacterial activity against $S$. aureus, a bacterial strain commonly found in postsurgery infections, has been investigated. The addition of copper has been shown to infer the glasses antibacterial properties. As expected, the antibacterial activity of the glasses increases with increasing $\mathrm{Cu}^{2+}$ content. Cytocompatibility was assessed by seeding human osteoblast-like osteosarcoma cells Saos-2 (HTB85) on the glass particles. A significant increase in cell number was observed in all the glasses investigated. The copper-doped calcium phosphate glasses have proven to be multifunctional, as they combine bone regenerative properties with antibacterial activity. Therefore, they have great potential as antibacterial bioresorbable materials for hard tissue regeneration.

KEYWORDS: calcium phosphate glasses, bone regeneration, controlled ion release, antibacterial activity

\section{INTRODUCTION}

Calcium phosphate glasses have been the subject of increased interest in recent years because of their potential application in the regeneration and repair of hard and soft tissues. ${ }^{1,2}$ They can be defined as bioresorbable, as they are able to interact with the physiological fluids producing the desired biological response and simultaneously dissolve completely over time, eventually being entirely replaced by regenerated tissue. ${ }^{3}$ Thanks to their complete solubility, they can be used as safe degradable temporary implants, avoiding the necessity of a second operation for their surgical removal. ${ }^{4}$ Moreover, they can be used as controlled local delivery systems of therapeutic molecules (e.g., antimicrobial ions/growth factors) that will be slowly released as the implant degrades. ${ }^{5}$ In particular, the addition of antimicrobial ions prevents biomaterial-related infections which often cause revision surgery. Their controlled delivery will avoid the systematic conventional administration treatments (oral and injection) that usually require higher doses of drugs that can cause toxic reactions. Currently, the most common bioresorbable materials are polymers (e.g.,

Received: August 21, 2019

Accepted: October 11, 2019

Published: October 11, 2019 
polylactic and polyglycolic acid). However, their degradation often results in crystalline fragments that could lead to toxicity. ${ }^{6}$ Differently from the polymer-based bioresorbable systems, phosphate-based glasses do not release any crystalline products which could lead to inflammation. Phosphate-based glasses also present a great advantage over silicate-based glasses which have a very slow solubility and therefore can only be used to manufacture long-term implants which are susceptible to long-term failure/inflammatory reactions. In addition, dissolution rate and ion release can be controlled and tailored according to the desired application by altering the glass composition. ${ }^{7}$ The most common method to prepare calcium phosphate glasses is using a conventional melt-quenching (MQ) technique that requires melting of oxide powders at temperatures $>1100{ }^{\circ} \mathrm{C}$ and rapid cooling. ${ }^{8}$ However, this method often leads to non-homogeneous glasses and loss of phosphorus. More recently, the sol-gel (SG) route has been proposed as an alternative technique for the synthesis of phosphate glasses. $^{9-13}$ However, phosphorus precursors (typically alkoxides) used in the sol-gel process are airsensitive and need to be dissolved in organic solvents. Moreover, gelation time can vary from few hours to days. Recently, a room temperature, water-based technique for the synthesis of undoped calcium pyrophosphate glasses was presented. $^{14,15}$ In this work, we used this single-step precipitation technique to synthesize a series of copperdoped calcium phosphate glasses containing $0,2,4$, and $6 \mathrm{~mol}$ $\% \mathrm{Cu}^{2+}$. To date, copper-doped phosphate glasses have only been prepared via MQ. ${ }^{16}$ In the very few papers published on the topic, copper has been shown to infer MQ phosphatebased glasses antibacterial property as the glasses degrade. ${ }^{17-19}$ When added to silicate-based glasses, copper has also shown promotion of osteogenesis and angiogenesis ${ }^{20}$ and increase in differentiation of mesenchymal stem cells toward the osteogenic lineage, ${ }^{21}$ in addition to antibacterial activity against Escherichia coli. ${ }^{22}$ In the present work, we have investigated antibacterial activity of copper-doped calcium phosphate glasses against Staphylococcus aureus (S. aureus), one of the most common pathogens associated with orthopedic device-related infections and antibiotic resistance. ${ }^{23}$

Bioresorbable calcium phosphate glasses find application mainly in bone tissue regeneration, as their composition is very similar to bone. ${ }^{2}$ New bone formation is stimulated through the release of $\mathrm{P}$ and $\mathrm{Ca}$ when the implant is exposed to an osseous defect. Previous in vitro cytocompatibility studies have been presented on the growth of bone cells on phosphatebased glasses prepared via MQ: human osteosarcoma derived cell lines MG63, ${ }^{6,24-26} \mathrm{HOS}^{26,27}$ primary-derived human osteoblasts, $^{28}$ and craniofacial osteoblasts. ${ }^{29}$ However, no previous works have been presented on the cytocompatibility of calcium phosphate glasses prepared via in solution, waterbased techniques. The present study has therefore investigated the biocompatibility of a series of copper-doped calcium phosphate glasses on the attachment and proliferation of the osteoblast-like cell line Saos-2 (HTB85) and the effect of addition of $\mathrm{Cu}^{2+}$ on the biocompatibility of the glasses.

\section{MATERIALS AND METHODS}

2.1. Synthesis. Amorphous calcium phosphate glasses were prepared using a method adapted from Slater et al. ${ }^{30}$ Fifty milliliters of $1 \mathrm{M}$ calcium chloride dihydrate $\left(\mathrm{CaCl}_{2} \cdot 2 \mathrm{H}_{2} \mathrm{O}\right.$, Sigma-Aldrich, $97 \%$ ) solution was added to a $50 \mathrm{~mL}$ solution of $0.2 \mathrm{M}$ potassium pyrophosphate $\left(\mathrm{K}_{4} \mathrm{P}_{2} \mathrm{O}_{7}\right.$, Sigma-Aldrich, $\left.97 \%\right)$ at a flow rate of $2 \mathrm{~mL} /$ min under vigorous stirring. The solution was then filtered via Buchner funnel immediately after addition of the $\mathrm{CaCl}_{2}$ solution. The precipitate was then washed twice, first with deionized water, then ethanol. The precipitate was then allowed to dry in air for 2 days. Copper-doped calcium phosphate glasses were synthesized by addition of $50 \mathrm{~mL}$ of $\mathrm{Cu}\left(\mathrm{NO}_{3}\right)_{2}$ (Acros Organics, 99\%) to the $\mathrm{CaCl}_{2}$ solution at different concentrations such that the total mol \% of $\mathrm{Cu}^{2+}$ was equal to 2,4 , and $6 \mathrm{~mol} \%$. The moles of $\mathrm{CaCl}_{2}$ were reduced to compensate for the addition of the $\mathrm{Cu}\left(\mathrm{NO}_{3}\right)_{2}$. This mixture was then added to the potassium pyrophosphate solution as previously described. To investigate the stability of the glasses under thermal treatment, we performed calcination at 200,400 , and $700{ }^{\circ} \mathrm{C}$ in air using a heating rate of $1{ }^{\circ} \mathrm{C} / \mathrm{min}$. The obtained glasses were ground at $10 \mathrm{~Hz}$ to form microparticles and then sieved (Endesotts Ltd., London, U.K.) to obtain particles in the size range of 200-300 $\mu \mathrm{m}$. Samples will be hereafter indicated as CPG (undoped) and CPG$\mathrm{CuX}$ (doped) where CPG stands for calcium phosphate glasses and X indicates the mol \% of $\mathrm{Cu}^{2+}$.

2.2. Characterization. Structural Characterization and Chemical Analysis. Scanning electron microscopy (SEM) was performed with a JSM-7100F, Jeol field emission electron microscope. A fixed accelerating voltage of $15 \mathrm{kV}$ was used with variable probing currents. Samples were mounted on aluminum sample holders using graphite paste and coated with graphite.

Energy Dispersive X-ray spectroscopy (EDX) was performed using a WDS MagnaRay Spectrometer was performed to determine the exact compositions of the prepared samples. SEM was operated at 20 $\mathrm{kV}$, spot size 6 and a working distance of $10 \mathrm{~mm}$.

X-ray diffraction (XRD) was performed using PANalytical X'Pert on samples in a flat plate geometry using $\mathrm{Ni}$ filtered $\mathrm{Cu} \mathrm{K} \alpha$ radiation $(\lambda=1.5418 \AA$ ). Data was collected using a PIXcel-1D detector with a step size of $0.05^{\circ}$ over an angular range of $2 \theta=10-90^{\circ}$ and a count time of $12 \mathrm{~s}$ per step.

Simultaneous thermogravimetric analysis (TGA) and differential scanning calorimetry (DSC) were performed on a TA InstrumentsSDT Q600 in air in the range $25-1000{ }^{\circ} \mathrm{C}$ at a heating rate of $10^{\circ} \mathrm{C} /$ min in an alumina crucible.

${ }^{31} \mathrm{P}$ magic-angle spinning solid-state nuclear magnetic resonance (MAS NMR) data were acquired at ambient temperature $\left(\sim 25^{\circ} \mathrm{C}\right)$ using a Bruker AVANCE III-500 spectrometer operating at a ${ }^{31} \mathrm{P}$ Larmor frequency of $202.46 \mathrm{MHz}$. All measurements were facilitated using a Bruker $4 \mathrm{~mm}$ dual channel HX probe MAS frequencies of 12 $\mathrm{kHz}$ for this study. These ${ }^{31} \mathrm{P}$ MAS NMR data were acquired using single-pulse (direct detection) methods and the pulse calibration and chemical shift referencing was performed using solid the secondary reference ammonium dihydrogen phosphate $\left(\mathrm{NH}_{4} \mathrm{H}_{2} \mathrm{PO}_{4}, \delta 0.9 \mathrm{ppm}\right)$ with respect to the IUPAC primary reference of $85 \% \mathrm{H}_{3} \mathrm{PO}_{4}(\delta 0.0$ $\mathrm{ppm})$. An $\pi / 2$ excitation pulse of $3 \mu \mathrm{s}$ and a recycle delay of $60 \mathrm{~s}$ were used in all experiments; this relaxation delay was checked against longer recycle delays to ensure full spin-lattice $\left(T_{1}\right)$ relaxation. Between 20 and 88 transients were acquired for each measurement, and all spectra were simulated using the Dmfit software package. ${ }^{31}$

Raman spectroscopy was performed on a DXR, Thermo Fisher Scientific at a $532 \mathrm{~nm}$ using a $10 \mathrm{~mW}$ power beam laser in the range of $1400-200 \mathrm{~cm}^{-1}$.

2.3. Dissolution Study. In order to assess the species released upon dissolution, $10 \mathrm{mg}$ of each glass composition were immersed in $10 \mathrm{~mL}$ deionized water for $1,3,5$, and 7 days with three replicates for each conditions $(n=3)$. The resulting suspensions for each time points were then centrifuged at $4800 \mathrm{rpm}$ for $10 \mathrm{~min}$ to separate the glass particles from the solution. Calcium, phosphorus, and copper in solution were subsequently measured by inductively coupled plasmaoptical emission spectroscopy (ICP-OES 720ES, Varian) calibrated across the predicted concentration range using a standard solution (ICP multielement standard solution, VWR). Both samples and standards were diluted $1: 1$ in $4 \% \mathrm{HNO}_{3}$ (Fluka) and analyzed in reference to a blank $\left(2 \% \mathrm{HNO}_{3}\right)$ solution under standard operating conditions.

2.4. Antibacterial Studies. The bactericidal effect of the synthesized glasses was determined using the quantitative agar 
Table 1. Compositions of the Glasses Measured by EDX

\begin{tabular}{|c|c|c|c|c|c|c|c|c|c|c|c|}
\hline \multirow[b]{2}{*}{ sample } & \multicolumn{5}{|c|}{ element wt \% } & \multicolumn{5}{|c|}{ element mol \% } & \multirow[b]{2}{*}{$\mathrm{Ca} / \mathrm{P}$} \\
\hline & $\mathrm{P}$ & $\mathrm{Ca}$ & $\mathrm{K}$ & $\mathrm{Cu}$ & $\mathrm{O}$ & $\mathrm{P}$ & $\mathrm{Ca}$ & $\mathrm{K}$ & $\mathrm{Cu}$ & $\mathrm{O}$ & \\
\hline CPG & 20.9 & 28.5 & 3.3 & & 47.3 & 15.2 & 16.1 & 1.9 & & 66.8 & 1.0 \\
\hline CPG-Cu2 & 19.9 & 22.1 & 3.1 & 6.2 & 48.6 & 14.6 & 12.5 & 1.8 & 2.2 & 68.9 & 0.9 \\
\hline CPG-Cu4 & 20.9 & 21.4 & 2.6 & 12.0 & 43.2 & 16.2 & 12.8 & 1.6 & 4.5 & 64.9 & 0.8 \\
\hline CPG-Cu6 & 18.9 & 13.3 & 2.6 & 17.2 & 48.1 & 14.3 & 7.7 & 1.6 & 6.3 & 70.1 & 0.5 \\
\hline
\end{tabular}

dilution method (ADM) as described by Gutierrez et al. ${ }^{32}$ Universal tubes with $10 \mathrm{~mL}$ of tryptic soy broth (TSB) were inoculated with $100 \mathrm{mg}$ of each glass powders and an overnight culture of $S$. aureus at $1 \times 10^{6} \mathrm{CFU} / \mathrm{mL}$. The $S$. aureus strain used was recently isolated and sequenced as reported by Stedman et al..$^{33}$ sharing a $99 \%$ of identity with the standard strain NCTC 7447 . Tubes were incubated at $37^{\circ} \mathrm{C}$ for 1 week at $250 \mathrm{rpm}$ and samples were collected after 1, 3, 5, and 7 days to calculate viable $\mathrm{CFU} / \mathrm{mL}$ of $S$. aureus for each time point. The overnight bacterial cultures were obtained in TSB at $37^{\circ} \mathrm{C}$ for $24 \mathrm{~h}$, at $250 \mathrm{rpm}$ and the experiments were conducted as two biological replicates; the glass containing no copper was used as negative control.

2.5. Cytocompatibility Assessment. 2.5.1. Cell Culture. Saos-2 (HTB85) osteosarcoma cells were procured from ATCC and cultured in McCoy's 5a medium (ATCC) with 15\% fetal bovine serum (FBS, Gibco, Invitrogen) and $1 \%$ antibiotic-antimycotic (Thermo Scientific) in a humidified incubator at $5 \% \mathrm{CO}_{2}$ and $37{ }^{\circ} \mathrm{C}$. On reaching $90 \%$ confluency, cells were passaged and used for cytocompatibility analysis for the materials. To facilitate the attachment of the cells on to the materials, we used polycarbonate cell culture inserts with 0.4 $\mu \mathrm{m}$ pore size (Merck Millipore). Materials were placed on the insets and incubated with medium overnight, and then $1.2 \times 10^{4}$ cells were placed in each insert with the different materials and cultured for 5 days with cell viability assessment during the culture period. Cells only on inserts were used as control for comparison purposes.

2.5.2. Cell Attachment and Growth. SEM was used to visualize cell attachment and growth on glass surfaces. At the end of day 5 , cells were fixed with $3 \%$ glutaraldehyde (Sigma-Aldrich) followed by dehydration using graded ethanol. Samples were then air-dried, gold sputter-coated, and visualized using a JEOL JSM7100F scanning electron microscope.

2.5.3. Alamar Blue Cell Viability Assay. An Alamar Blue assay was carried out on days 1,3 , and 5 to assess cell viability and growth. Cells were incubated for $2 \mathrm{~h}$ in a $10 \%$ Alamar Blue solution (ThermoFisher) followed by fluorescence measurement with a BioTek plate reader at $530 \mathrm{~nm}$ excitation and $590 \mathrm{~nm}$ emission as a direct estimation of cell growth on the different materials.

2.5.4. DAPI-Phalloidin staining. At the end of day 5, the cells were fixed using $4 \%$ paraformaldehyde and stained with DAPI-phalloidin for visualization of the nucleus and actin filaments. Cells were incubated for $20 \mathrm{~min}$ at room temperature in staining solution containing $2.5 \mu \mathrm{L}$ of DAPI $(1 \mathrm{mg} / \mathrm{mL}$ stock solution, Thermo Scinetific), $4 \mu \mathrm{L}$ of phalloidin ( $200 \mathrm{U} / \mathrm{ml}$ stock concentration, Alexa Fluor 488, Phalloidin, Life Technologies), and $20 \mu \mathrm{L}$ of Triton $\mathrm{X}$ per $\mathrm{ml}$ of PBS. Cells were then visualized using a Cytation5 cell imaging multimode reader (Biotek).

\section{RESULTS}

3.1. Assessment of Glass Composition. Chemical analysis of the samples was carried out using a SEM equipped with an EDX detector. Elemental compositions in terms of weight percent and mole percent are reported in Table 1 . The $\mathrm{Ca} / \mathrm{P}$ of the undoped sample is equal to 1.0 and it corresponds to the pyrophosphate stoichiometry. This is in agreement with the synthesis used, which was designed to produce calcium pyrophosphate glasses. $^{30}$ The $\mathrm{Ca} / \mathrm{P}$ ratio decreases as the copper content increases as expected given that the calcium was replaced with copper in the synthesis. Therefore, as expected, in the doped samples, the $\mathrm{Ca}$ amount decreases as the copper amount increases. The $\mathrm{Ca} / \mathrm{P}$ molar ratio, which varies between 1.0 and 0.5 , is in agreement with the $\mathrm{Ca} / \mathrm{P}$ molar ratio found in the majority of calcium phosphate phases of biomedical interest, which varies between 1.0 and $0.5 .^{34} \mathrm{It}$ has to be noted that a small amount of potassium is also present in all glasses. Residual potassium was also found in undoped calcium pyrophosphate glasses prepared with the same synthetic protocol. ${ }^{30}$

A representative EDX spectrum used to calculate the elemental compositions and a representative EDX chemical map used to evaluate distribution of all elements are shown in Figure $1 \mathrm{~A}$ and $\mathrm{B}$, respectively. The EDX map shows that the distribution of all elements on the surface of the glass particles is highly homogeneous, including the dopant copper.
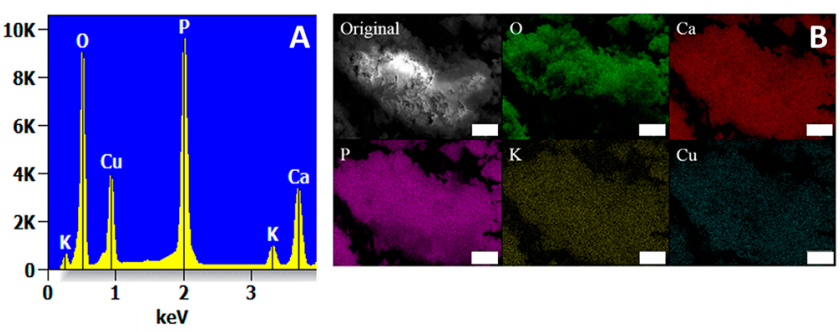

Figure 1. (A) EDX spectrum and (B) EDX mapping of the representative sample CPG-Cu6. Scale bar is $10 \mu \mathrm{m}$.

3.2. Thermogravimetric Analysis. Weight loss of all glasses and identification of thermal events upon heating were assessed using simultaneous differential scanning calorimetry (DSC) and thermogravimetric analysis (TGA). TGA and DSC curves are shown in Figure 2 and main weight losses and crystallization temperatures are reported in Table 2. All samples exhibit one main weight loss (16.8-20.0\%) between 25 and $150{ }^{\circ} \mathrm{C}$. This event, which corresponds to a broad endothermic peak in the DSC trace, can be ascribed to dehydration of the sample. The total weight loss is similar for all the $\mathrm{Cu}^{2+}$-doped samples (about $21 \%$ ) and slightly higher for the undoped glass (about 24\%). A single sharp exothermic peak is observed between 533 and $625{ }^{\circ} \mathrm{C}$ in all samples, ascribed to the crystallization of the glass.

3.3. X-ray Diffraction. XRD patterns of all samples, reported in Figure 3, clearly show absence of Bragg peaks indicating that all samples are amorphous. The only feature observed is the broad halo around $28^{\circ}$ which is due to the amorphous phosphate network. Therefore, the introduction of $\mathrm{Cu}^{2+}$ even up to $6 \mathrm{~mol} \%$ does not induce crystallization. In order to assess the thermal stability, glasses were then calcined at 200, 400, and $700{ }^{\circ} \mathrm{C}$. As shown in Figure S1, the XRD patterns of all samples calcined up to $400{ }^{\circ} \mathrm{C}$ are still amorphous. However, after calcination at $700{ }^{\circ} \mathrm{C}$, full crystallization occurs with formation of calcium pyrophosphate 

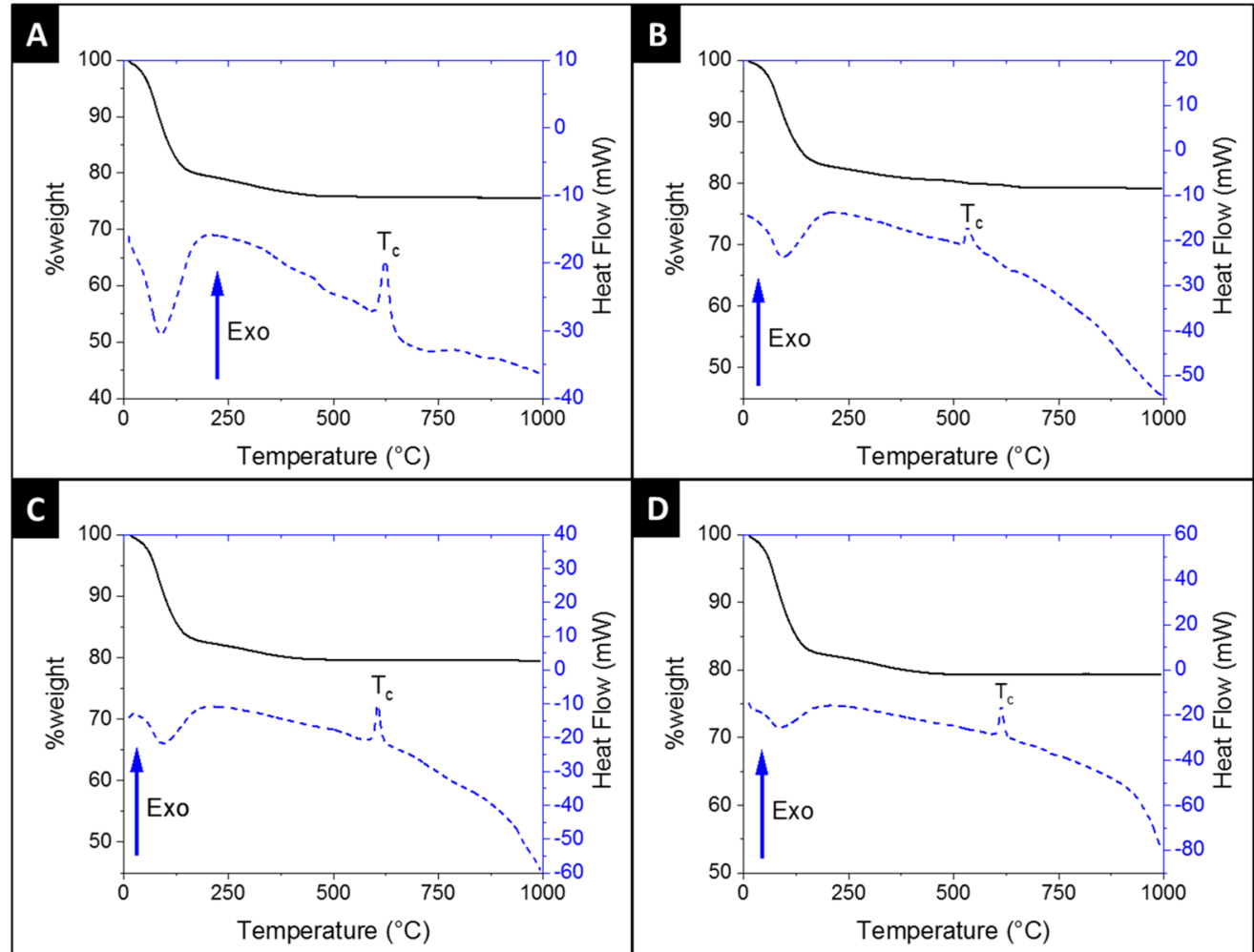

Figure 2. TGA (dotted line) and DSC (solid line) of (A) CPG, (B) CPG-Cu2, (C) CPG-Cu4, and (D) CPG-Cu6.

Table 2. Weight Loss \% and Crystallization Temperatures $\left(T_{\mathrm{c}}\right)$ Obtained from TGA and DSC Plots

\begin{tabular}{lccc} 
sample & $\begin{array}{c}\text { weight loss } \% \text { in the range } \\
25-150{ }^{\circ} \mathrm{C}\end{array}$ & $\begin{array}{c}\text { total weight } \\
\text { loss } \%\end{array}$ & $\begin{array}{c}T_{\mathrm{C}} \\
\left({ }^{\circ} \mathrm{C}\right)\end{array}$ \\
\hline CPG & 20.0 & 24.3 & 625 \\
CPG-Cu2 & 17.0 & 20.8 & 533 \\
CPG-Cu4 & 16.8 & 20.5 & 606 \\
CPG-Cu6 & 17.0 & 20.7 & 614 \\
\hline
\end{tabular}

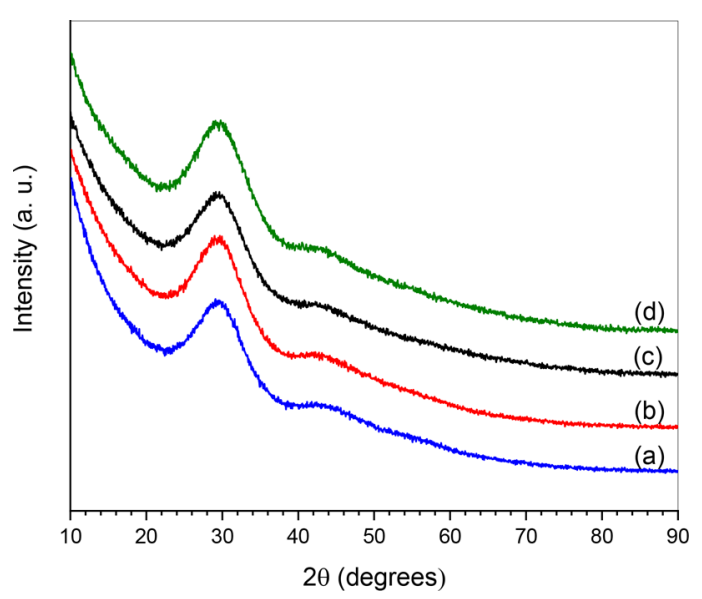

Figure 3. XRD patterns of (a) CPG, (b) CPG-Cu2, (c) CPG-Cu4, and (d) CPG-Cu6.

$\alpha-\mathrm{Ca}_{2} \mathrm{P}_{2} \mathrm{O}_{7}$ (ICDD card 09-0345). XRD results are in fully agreement with the DSC results as Bragg peaks are evident only in the samples calcined at $700{ }^{\circ} \mathrm{C} .{ }^{3}$

3.4. ${ }^{31} \mathrm{P}$ MAS NMR. The ${ }^{31} \mathrm{P}$ MAS NMR technique was used to characterize the local environment around each phosphorus species. The ${ }^{31} \mathrm{P}$ MAS NMR data presented in
Figure 4 show resonances that are assigned to $Q^{\mathrm{n}}$ groups, where $\mathrm{n}$ represents the number of bridging oxygens between phosphate units. Spectral parameters are presented in Table 3. In all samples, the predominant resonance is located at a chemical shift of approximately $-6 \mathrm{ppm}$, which is typical of the $\mathrm{Q}^{1}$-type pyrophosphate unit $\left(\mathrm{P}_{2} \mathrm{O}_{7}{ }^{4-}\right) \cdot{ }^{36} \mathrm{~A}$ contribution from $\mathrm{Q}^{0}$ groups which is attributed to isolated tetrahedral orthophosphate $\left(\mathrm{PO}_{4}{ }^{3-}\right)$ units is also observed in all samples in the chemical shift range of approximately -2.8 to $1.8 \mathrm{ppm}$. The presence of $\mathrm{Q}^{0}$ groups can be ascribed to the partial hydrolysis of some of the pyrophosphate ions during the synthesis of $\mathrm{CPG}$ or to $\mathrm{PO}_{4}{ }^{3-}$ units contained in the precursors during the synthesis. ${ }^{30,37}$ From Figure 4 it can be observed that only $\mathrm{Q}^{0}$ and $\mathrm{Q}^{1}$ groups are observed to constitute the CPG and CPG-Cu2 systems; however, CPG-Cu4 and CPG-Cu6 show an additional resonance at around $-16 \mathrm{ppm}$, which is ascribed to the formation of polymeric $-\mathrm{P}-\mathrm{O}-\mathrm{P}-\left(\mathrm{Q}^{2}\right)$ groups. From the compositions of these systems outlined in Table 1 , an increase in copper content coincides with a marked decrease in network modifying $\mathrm{Ca}$ speciation thus leading to the formation of some polymeric $-\mathrm{P}-\mathrm{O}-\mathrm{P}-\left(\mathrm{Q}^{2}\right)$ groups. It is unlikely that this observed shift corresponds to a $-\mathrm{Cu}-\mathrm{O}-\mathrm{P}-$ linkage as the strongly paramagnetic $\mathrm{Cu}^{2+}$ species would broaden the nearby $\mathrm{P}$ position beyond detection. Indeed, not all of the $\mathrm{P}$ speciation will be observed in the ${ }^{31} \mathrm{P}$ MAS NMR experiment as those positons proximate (i.e., nearest neighbor) to the introduced $\mathrm{Cu}^{2+}$ species will paramagnetically broadened beyond detection; this phenomenon becomes more prominent as the copper content increases. From Figure 4, the relative intensity of $\mathrm{Q}^{\mathrm{n}}$ groups changes with increasing $\mathrm{Cu}^{2+}$ content and a concomitant decreasing $\mathrm{Ca}^{2+}$ content. The undoped CPG sample exhibits a predominance of $\mathrm{Q}^{1}$ groups (integrated intensity of $\sim 98 \%$ ) is in agreement with the pyrophosphate stoichiometry confirmed by the $\mathrm{Ca} / \mathrm{P}$ ratio calculated using 

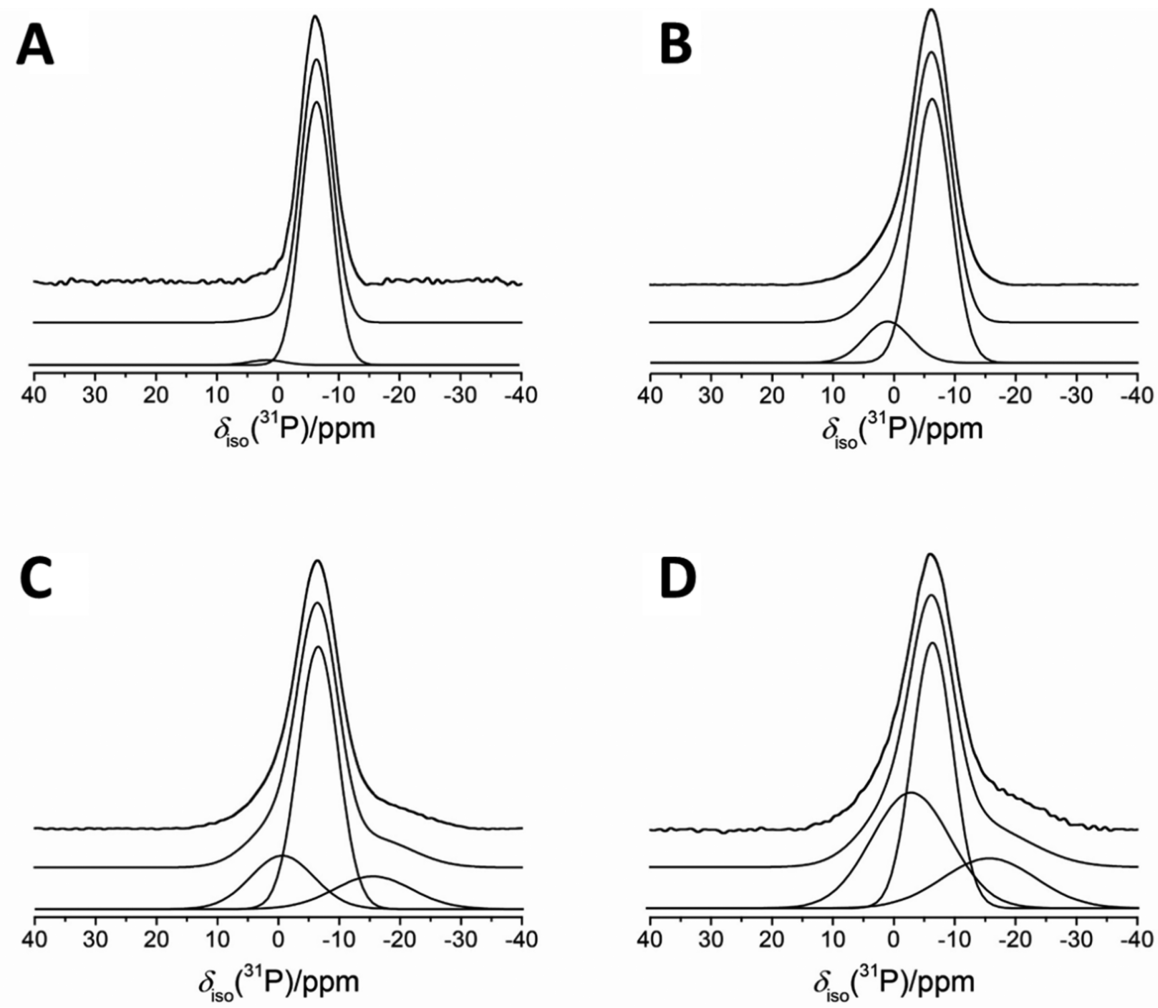

Figure 4. ${ }^{31} \mathrm{P}$ MAS NMR spectra of (A) CPG, (B) CPG-Cu2, (C) CPG-Cu, and (D) CPG-Cu6. The lines from top to bottom are raw NMR signal, cumulative fit, and deconvoluted peaks.

Table 3. ${ }^{31}$ P MAS NMR Spectral Parameters (chemical shift, $\left.\delta_{\text {iso }}\right)$ and Relative Intensity (I \%)) Obtained by Signal Deconvolution Achieved Using the DMFit Post-Processing Program

\begin{tabular}{|c|c|c|c|c|c|c|}
\hline & \multicolumn{2}{|c|}{$Q^{0}$} & \multicolumn{2}{|l|}{$Q^{1}$} & \multicolumn{2}{|l|}{$Q^{2}$} \\
\hline & $\delta_{\text {iso }}(\mathrm{ppm})$ & $I \%$ & $\delta_{\text {iso }}(\mathrm{ppm})$ & $I \%$ & $\delta_{\text {iso }}(\mathrm{ppm})$ & I \% \\
\hline CPG & 1.8 & 2.1 & -6.4 & 97.9 & & \\
\hline CPG-Cu2 & 1.0 & 16.0 & -6.3 & 84.0 & & \\
\hline CPG-Cu4 & -0.6 & 20.6 & -6.5 & 63.9 & -15.5 & 15.5 \\
\hline CPG-Cu6 & -2.8 & 37.1 & -6.4 & 43.5 & -15.7 & 18.9 \\
\hline
\end{tabular}

EDX, with only $\sim 2 \%$ of the $\mathrm{P}$ speciation in this sample comprising $\mathrm{Q}^{0}$ units. The CPG-Cu2 system shows that the relative intensity of $\mathrm{Q}^{1}$ groups decreases to $\sim 84 \%$, with the remaining $\sim 16 \%$ of the $\mathrm{P}$ speciation represented by $\mathrm{Q}^{0}$ units. However, the CPG-Cu4 and CPG-Cu6 systems exhibit the onset of $\mathrm{Q}^{2}$ formation as the relative intensity of the $\mathrm{Q}^{1}$ groups decreases to 63.9 and $43.5 \%$, respectively.

3.5. Raman Spectroscopy. Raman spectra of all glasses are presented in Figure 5. All bands are quite broad, confirming the amorphous nature of all samples. Bands in the frequency region between 200 and $950 \mathrm{~cm}^{-1}$ arise from vibrations of the in-chain $\mathrm{P}-\mathrm{O}-\mathrm{P}$ bonds, whereas bands in the frequency region between 950 and $1400 \mathrm{~cm}^{-1}$ arise from out-of-chain $\left(\mathrm{PO}_{3}\right)^{2-} \cdot{ }^{8}$ The predominant bands that occur at 770 and 1050 $\mathrm{cm}^{-1}$ are typical of short-chain $\mathrm{Q}^{1}$-type pyrophosphate $\left(\mathrm{P}_{2} \mathrm{O}_{7}{ }^{4-}\right)$, in agreement with ${ }^{31} \mathrm{P}$ MAS NMR data. They can be assigned to the symmetric stretching mode of $\mathrm{P}-\mathrm{O}-\mathrm{P}$ in very short chains and $\left(\mathrm{PO}_{3}\right)^{2-}$ terminal groups, respectively. ${ }^{39}$ Typical bending vibrations of a network structure dominated by pyrophosphate groups are observed in the range 480-650 $\mathrm{cm}^{-1} \cdot{ }^{40,15}$ Another significant band occurs at $340 \mathrm{~cm}^{-1}$ that is

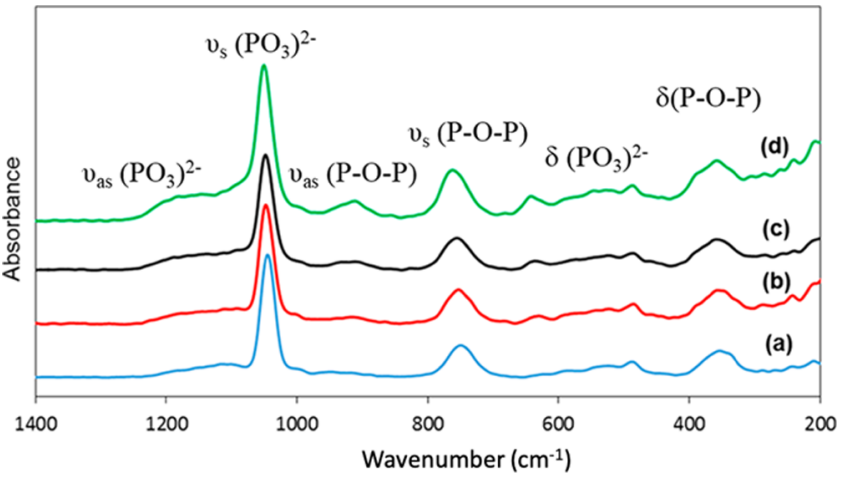

Figure 5. Raman spectra of (a) CPG, (b) CPG-Cu2, (c) CPG-Cu4, and (d) CPG-Cu6.

due to bending of $\left(\mathrm{PO}_{4}\right)^{3-}$ units linked to $\mathrm{Ca}^{2+}$ and/or $\mathrm{Cu}^{2+}$ as cation modifiers. ${ }^{41}$ The broad band at $1190 \mathrm{~cm}^{-1}$ can be attributed to asymmetric stretching motions of the $\left(\mathrm{PO}_{3}\right)^{2-}$ groups. ${ }^{15}$ This band becomes more prominent as the $\mathrm{Cu}^{2+}$ content increases, in agreement with similar zinc-doped MQ phosphate glasses. ${ }^{38}$ The band at $930 \mathrm{~cm}^{-1}$ is due to asymmetric stretching of $\mathrm{P}-\mathrm{O}-\mathrm{P}$.

3.6. Dissolution Study. The concentrations of phosphorus, calcium, and copper released in water at different time points up to 7 days are presented in Figure 6A-C, respectively. $\mathrm{P}$ and $\mathrm{Ca}$ ion release profiles do not change significantly with copper loading in the first $24 \mathrm{~h}$. However, clear differences can be seen in the release profiles of the following 7 days. In particular, the CPG copper-free glasses release the highest amount of $\mathrm{P}$ and $\mathrm{Ca}$ which then decreases with increasing the copper content. Decrease in $\mathrm{P}$ release could be related to the cross-linking effect of $\mathrm{Cu}^{2+}$ that makes the phosphate chains 

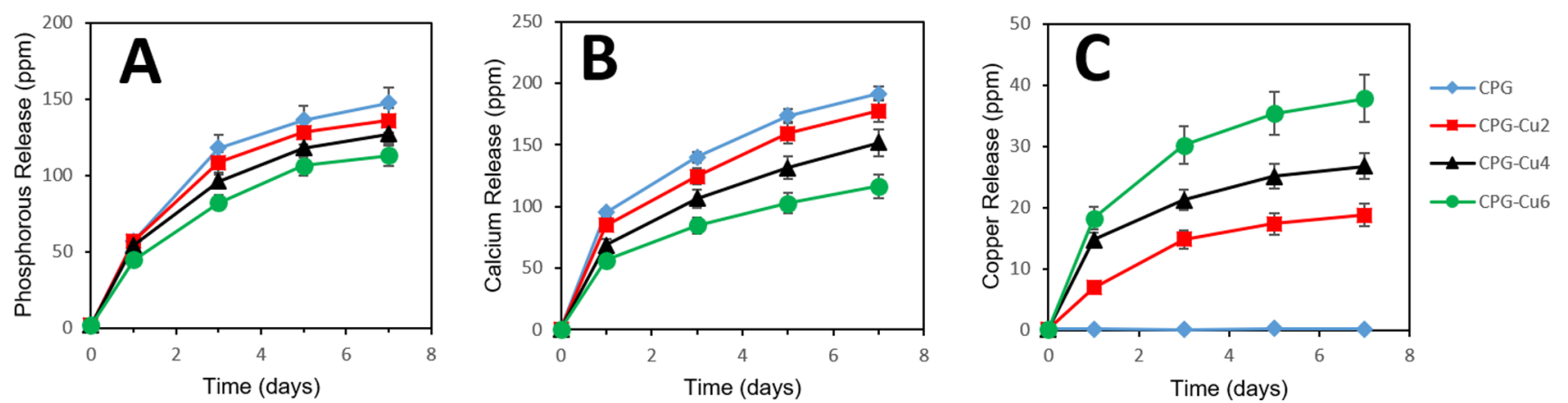

Figure 6. Release of (A) phosphorus, (B) calcium, and (C) copper in deionized water as a function of time for all glasses measured by ICP-OES.

more interconnected, increasing their strength in solution. A decrease in $\mathrm{Ca}$ is expected as $\mathrm{Ca}^{2+}$ is replaced with $\mathrm{Cu}^{2+}$ in the synthesis. Release of $\mathrm{Cu}^{2+}$ ions clearly increases with copper content. Moreover, differently from the release of $\mathrm{P}$ and $\mathrm{Ca}$, differences can be seen in the first $24 \mathrm{~h}$, with CPG-Cu2 releasing less copper that CPG-Cu4 and CPG-Cu6.

3.7. Antimicrobial Study. A quantitative $\mathrm{ADM}$ assay was performed on the dissolution products of the glasses when in contact with $S$. aureus strain for 7 days (Figure 7 ). In all the

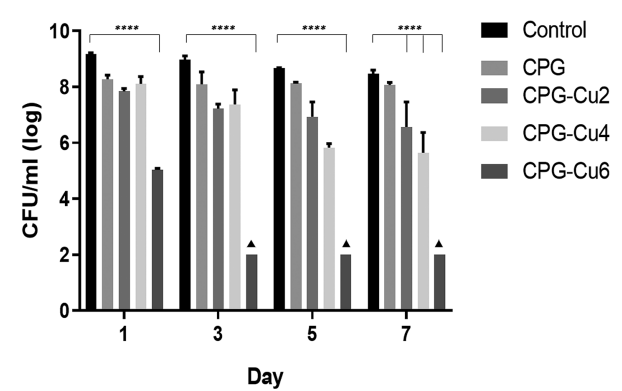

Figure 7. Antibacterial activity of all glasses against $S$. aureus expressed as the mean \pm standard deviation (error bars) $(*=p<$ $0.05, * * * *=p<0.0001 ; \boldsymbol{\Delta}=$ minimum bacterial $\mathrm{CFU} / \mathrm{mL}$ detection point).

experiments, growth of $S$. aureus strain was used as a control. The bacterial viability is expressed as $\log 10 \mathrm{CFU} / \mathrm{mL}(\mathrm{CFU}=$ colony forming units) and error bars represent standard deviations (two-way ANOVA for each time point). Three runs for each experiment were performed to validate the results. As expected, the antibacterial activity increases with increasing $\mathrm{Cu}^{2+}$ content. $\mathrm{CPG}-\mathrm{Cu} 2$ and $\mathrm{CPG}-\mathrm{Cu} 4$ show a progressive reduction in the $\log 10$ of the mean number of viable counts from day 1 to 7 . They show similar antibacterial activities at day 1 and day 3 when the reduction is statistically significant for both $(1 \log 10$ reduction, $p$ value $<0.017$ at day 1 ; and 2 $\log 10$ reduction, $p$ value $>0.005$ at day 3 ). At day 5 they both increase their antibacterial activity; however, the increase is much higher for CPG-Cu4 (more than $1 \log 10$ reduction in the numbers of CFU compared to those for the control). The activity does not change again until day 7. CPG-Cu6 glass is highly active even after 1 day of incubation, as it achieved a 5 $\log 10$ reduction, demonstrating a rapid bactericidal effect. Its activity then increases up to day 3 ( $8 \log 10$ reduction) and then stays constant at days 5 and 7.

Interestingly, the undoped CPG sample shows a mild antibacterial activity that does not change over time. The same effect has been previously been observed in phosphate-based glasses prepared by $\mathrm{MQ}^{42}$ and silicate-based glasses. ${ }^{43}$ It has been suggested that this could be due to a change in $\mathrm{pH}$ values during glass degradation.

3.8. In Vitro Biocompatibility Assessment. Biocompatibility of all glasses was assessed by evaluating attachment and viability of Saos-2 osteosarcoma cells cultured on their surfaces. These cells were selected because they possess several osteoblastic features and can therefore be used to mimic the osteoblast response to the glasses. ${ }^{44,45}$ Cell attachment was assessed via SEM and DAPI-phalloidin staining. SEM images reported in Figure 8 show that Saos- 2 cells are attached and

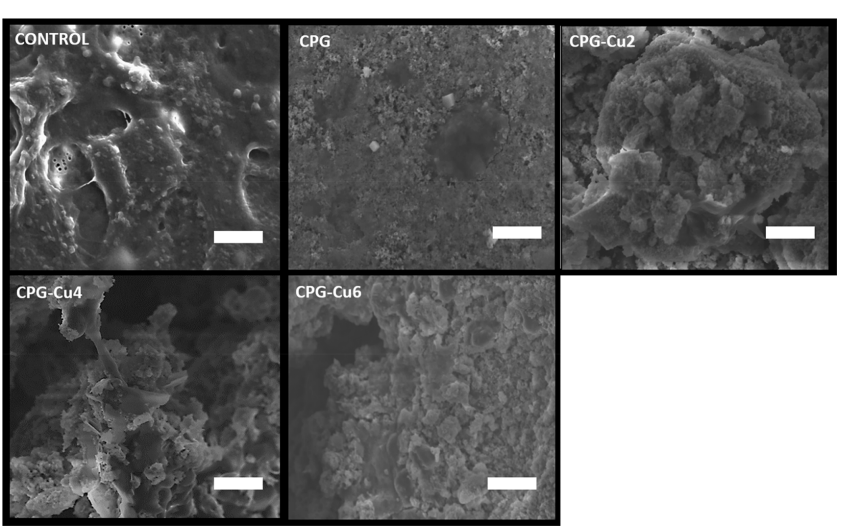

Figure 8. SEM images showing viability of Saos- 2 cells when seeded onto the glasses after 5 days. Scale bar is $10 \mu \mathrm{m}$.

well spread on the surface of all glasses over a five-day period. Cells form aggregates with flat morphology nicely attached over the surface of the glasses.

SEM results are confirmed by qualitative analysis based on DAPI-phalloidin staining (Figure 9). Cell nuclei (blue) and filaments (green) show that cells are attached and spread on all glass surfaces after 5 days of seeding.

Cell viability was then quantitatively assessed using the Alamar Blue assay. The graph shown in Figure 10 represents the change in fluorescence of Alamar Blue dye as a direct indicator of cellular metabolic activity which is directly linked to the number of cells. Within each glass composition, cell growth does not change significantly from day 1 to day 3 . However, from day 3 to day 5, all glasses show a significant increase in cell proliferation. The highest cell growth was observed for the undoped sample CPG at day 5, which is very similar to the control. All $\mathrm{Cu}^{2+}$ doped samples also show high metabolic activity at day 5 . However, their activity decreases as the $\mathrm{Cu}^{2+}$ content increases. 


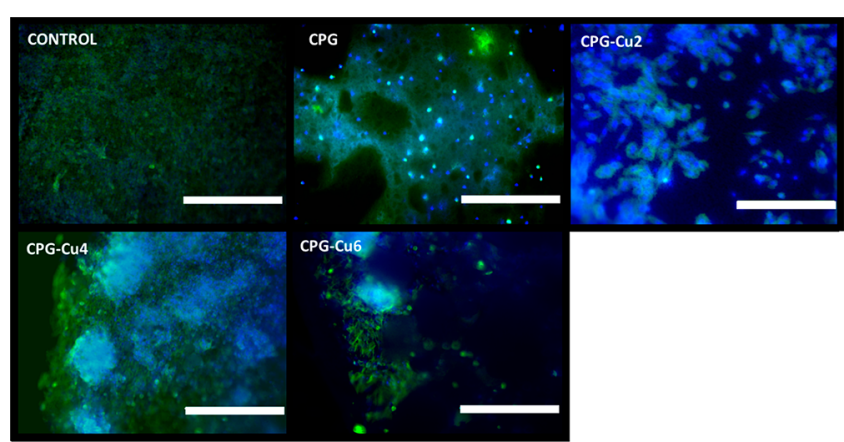

Figure 9. DAPI- phalloidin staining of Saos-2 cells seeded onto the glasses after 5 days. The green fluorescent stain (phalloidin) shows filamentous actin and the blue (DAPI) shows nuclei. Scale bar is 400 $\mu \mathrm{m}$.

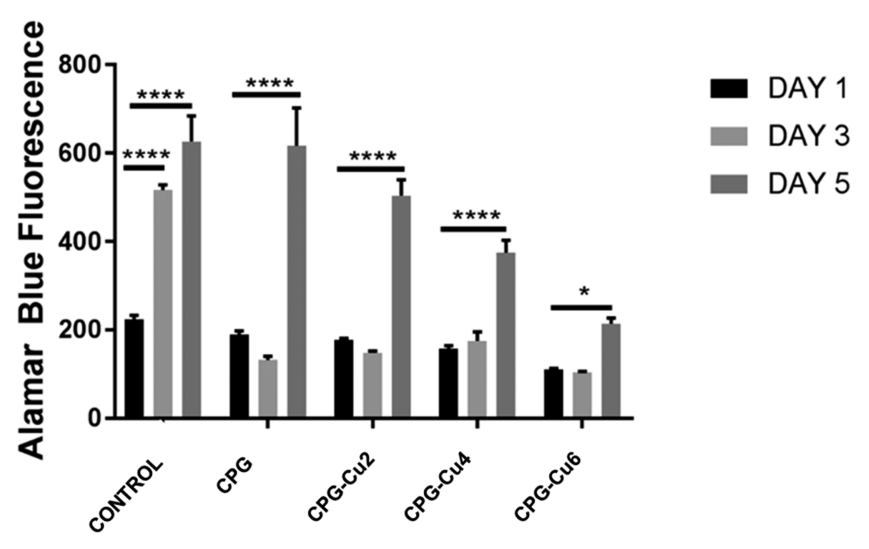

Figure 10. Cell viability measurement using the Alamar blue fluorescence assay after 1, 3, and 5 days in culture. Error bars are $\operatorname{SD}(n=3) . *=p<0.05 ; * * * *=p<0.0001$.

\section{DISCUSSION}

Calcium phosphate glasses have been widely investigated as multifunctional biomaterials capable of inducing bone tissue regeneration and simultaneously release of drug molecules in a controlled manner. However, the majority of the works presented so far refer to glasses prepared using the high temperature melt-quenching technique and in less extent using the sol-gel method. Moreover, very few studies refer to glasses doped with copper as an antibacterial ion. This study investigates the structure, antibacterial activity and biocompatibility of copper-doped phosphate-based glasses prepared using a water-based, room temperature technique.

XRD patterns and DSC analysis show that all glasses are amorphous up to $\sim 530-600{ }^{\circ} \mathrm{C}$ depending on the composition. Crystallization temperatures are close to those reported for undoped phosphate glasses prepared via $\mathrm{MQ}$ $\left(\sim 450-650{ }^{\circ} \mathrm{C}\right)^{7}$ and via SG $\left(\sim 500{ }^{\circ} \mathrm{C}\right) .{ }^{46}$ Crystallization of copper-doped MQ fibers have also been reported around 500$550{ }^{\circ} \mathrm{C} .{ }^{18}$ The thermal stability of the systems prepared in this work is therefore comparable with that of MQ and SG systems.

${ }^{31} \mathrm{P}$ MAS NMR study has shown that in all glasses, $\mathrm{Q}^{1}$ is the predominant group. Predominance of $\mathrm{Q}^{1}$-type groups is also confirmed by the predominant bands that occur at 770 and $1050 \mathrm{~cm}^{-1}$ in the Raman spectra. This is significantly different from the majority of bioresorbable calcium phosphate glasses presented in the literature that have $\mathrm{Q}^{2}$ as predominant group.
What species were released from the glasses when immersed in water was monitored over a period of 7 days. The release of $\mathrm{P}$ and $\mathrm{Ca}$ followed a similar pattern, with very similar release occurring in the first $24 \mathrm{~h}$ for all compositions, followed by a progressive decrease in $\mathrm{P}$ and $\mathrm{Ca}$ release with increasing $\mathrm{Cu}$ content over 7 days. These results are in agreement with ${ }^{31} \mathrm{P}$ MAS NMR data, as $\mathrm{Cu}^{2+}$ seems to decrease the dissolution rate of $\mathrm{P}$ and $\mathrm{Ca}$, confirming the cross-linking effect. This shows that the degradation of the glasses can be tailored by optimizing the addition of $\mathrm{Cu}^{2+}$ as a dopant. The amount of $\mathrm{Cu}^{2+}$ released increases with its content in agreement with $\mathrm{Cu}^{2+}$ release results reported on MQ phosphate glass fibers. ${ }^{18}$ The same trend has been reported upon release of $\mathrm{Zn}^{2+}$ ions and $\mathrm{Sr}^{2+}$ from MQ phosphate glasses. 47,8

The antimicrobial effect of $\mathrm{Cu}^{2+}$ release was investigated against the Gram-positive bacteria $S$. aureus. It has to be noted that this is the first study of this kind being the previously reports limited to the antibacterial activity of phosphate-based glass fibers and bulk against S. epidermidis ${ }^{18,48}$ and biofilms of S. sanguis. ${ }^{48}$ Antimicrobial studies demonstrate a strong positive correlation between $\mathrm{Cu}^{2+}$ concentration/release and bactericidal properties. The glass that contains and releases the highest amount of $\mathrm{Cu}^{2+}$ (CPG-Cu6) was shown to be the most effective in killing the bacteria, significantly reducing the number of viable bacteria from day 1 ( $5 \mathrm{log}$ reduction). The activity of CPG-Cu2 and CPG-Cu4 was also significant but mainly at day 5 .

Cytocompatibility assessment was carried out by putting in contact all synthesized glasses with Saos-2 osteosarcoma cells for a period of 5 days. Quantitative and qualitative analysis showed that copper-doped glasses were able to support attachment and expansion of Saos-2 cells. In particular, cell viability increases significantly at day 5 for all compositions. Same trend has been previously observed in $\mathrm{Cu}^{2+}$ doped silicate-based glasses. ${ }^{51}$ It has to be noted that a decrease in cell viability was observed with increasing $\mathrm{Cu}^{2+}$ concentration. This could be explained with the fact that high doses of $\mathrm{Cu}^{2+}$ increase the reactive oxygen species, leading to a decrease in cell viability. ${ }^{51} \mathrm{On}$ the basis of these results, a $\mathrm{Cu}$ amount of 2 mol \% seems to be the optimal composition for bone tissue engineering applications; CPG-Cu2 has been shown to deliver good antibacterial activity and simultaneously induce significant cell proliferation and growth at day 5 .

\section{CONCLUSIONS}

In this study, a series of calcium phosphate glasses containing $0,2,4$, and $6 \mathrm{~mol} \%$ of $\mathrm{Cu}^{2+}$ have been successfully synthesized using a room temperature, aqueous route. All samples prepared showed a good thermal stability being amorphous up to $\sim 530-600{ }^{\circ} \mathrm{C}$ depending on the copper content. ${ }^{31} \mathrm{P}$ MAS NMR and Raman spectroscopy have shown that the glasses are mainly formed by $\mathrm{Q}^{1}$ groups, with $\mathrm{Q}^{2}$ groups observed only in the 4 and $6 \mathrm{~mol} \% \mathrm{Cu}^{2+}$-doped glasses. Dissolution studies have shown that $\mathrm{P}$ release decreases with increasing $\mathrm{Cu}^{2+}$ content, suggesting a cross-linking effect of $\mathrm{Cu}^{2+}$ between phosphate chains, which is also supported by ${ }^{31} \mathrm{P}$ MAS NMR results. Calcium release also decreases with $\mathrm{Cu}^{2+}$ content due to the replacement of $\mathrm{Ca}^{2+}$ with $\mathrm{Cu}^{2+}$ during synthesis while $\mathrm{Cu}^{2+}$ release increases, as expected. The antibacterial activity of the glasses against $S$. aureus is dose dependent, as increases with $\mathrm{Cu}^{2+}$ content. In particular, the glass containing $6 \mathrm{~mol} \%$ of $\mathrm{Cu}^{2+}$ shows significant activity even after 1 day of incubation. Cytocompatibility studies have shown that 
osteoblast-like cells Saos-2 attach and spread on the surface of all glasses over a period of 5 days. Results have shown that viability of cells increases from day 1 to day 5 for all glass compositions, even if a decrease in cell viability is observed with increasing $\mathrm{Cu}^{2+}$ content. To conclude, this study has shown that copper-doped calcium phosphate glasses prepared using a mild, aqueous-based technique can be used as bioresorbable materials to prevent postsurgical infections and bone tissue regeneration.

\section{ASSOCIATED CONTENT}

\section{S Supporting Information}

The Supporting Information is available free of charge on the ACS Publications website at DOI: 10.1021/acsbiomaterials.9b01291.

XRD patterns of all glasses after calcination at 200, 400, and $700{ }^{\circ} \mathrm{C}(\mathrm{PDF})$

\section{AUTHOR INFORMATION}

\section{Corresponding Author}

*Email: d.carta@surrey.ac.uk.

\section{ORCID $\odot$}

John V. Hanna: 0000-0002-0644-3932

Jonathan C. Knowles: 0000-0003-3917-3446

Daniela Carta: 0000-0002-4344-4061

\section{Author Contributions}

${ }^{\dagger}$ F.F. and J.M. contributed equally to this work.

\section{Notes}

The authors declare no competing financial interest.

\section{ACKNOWLEDGMENTS}

The authors acknowledge EPSRC (Grant EP/P033636/1) and Royal Society (Grant RSG $\backslash R 1 \backslash 180191$ ) for providing the funding to conduct this study. The authors are also grateful to Dr D. Jones and Miss A. M. Nelson for their help with the SEM/EDX and Dr G. Palmer for his help with ICP-OES measurements. DC thanks the Doctoral College, University of Surrey and Fourth State Medicine Ltd for funding A.N.'s PhD studentship. J.V.H. thanks EPSRC, the University of Warwick, and the Birmingham Science City Program for partial funding of the solid-state NMR infrastructure at Warwick. The latter program accessed the Birmingham Science City Advanced Materials Project 1: Creating and Characterizing Next Generation Advanced Materials, which derived support from Advantage West Midlands (AWM) and the European Regional Development Fund (ERDF). N.L.K. thanks EPSRC for a PhD studentship through the EPSRC Centre for Doctoral Training in Molecular Analytical Science, Grant EP/L015307/1.

\section{REFERENCES}

(1) Abou Neel, E. A.; Pickup, D. M.; Valappil, S. P.; Newport, R. J.; Knowles, J. C. Bioactive Functional Materials: A Perspective on Phosphate-Based Glasses. J. Mater. Chem. 2009, 19 (6), 690-701.

(2) Islam, M. T.; Felfel, R. M.; Abou Neel, E. A.; Grant, D. M.; Ahmed, I.; Hossain, K. M. Z. Bioactive Calcium Phosphate-Based Glasses and Ceramics and Their Biomedical Applications: A Review. J. Tissue Eng. 2017, 8, 1-16.

(3) Knowles, J. C. Phosphate Based Glasses for Biomedical Applications. J. Mater. Chem. 2003, 13 (10), 2395-2401.

(4) Grover, L. M.; Wright, A. J.; Gbureck, U.; Bolarinwa, A.; Song, J.; Liu, Y.; Farrar, D. F.; Howling, G.; Rose, J.; Barralet, J. E. The Effect of Amorphous Pyrophosphate on Calcium Phosphate Cement
Resorption and Bone Generation. Biomaterials 2013, 34 (28), 6631-6637.

(5) Lapa, A.; Cresswell, M.; Jackson, P.; Boccaccini, A. R.; Lapa, A.; Cresswell, M.; Jackson, P.; Boccaccini, A. R.; Lapa, A.; Cresswell, M. Phosphate Glass Fibres with Therapeutic Ions Release Capability - a Review. Adv. Appl. Ceram. 2019, 1-14.

(6) Bitar, M.; Salih, V.; Mudera, V.; Knowles, J. C.; Lewis, M. P. Soluble Phosphate Glasses: In Vitro Studies Using Human Cells of Hard and Soft Tissue Origin. Biomaterials 2004, 25 (12), 2283-2292.

(7) Ahmed, I.; Lewis, M.; Olsen, I.; Knowles, J. C. Phosphate Glasses for Tissue Engineering: Part 1. Processing and Characterisation of a Ternary-Based $\mathrm{P}_{2} \mathrm{O}_{5}-\mathrm{CaO}-\mathrm{Na}_{2} \mathrm{O}$ Glass System. Biomaterials 2004, 25 (3), 491-499.

(8) Al Qaysi, M.; Walters, N. J.; Foroutan, F.; Owens, G. J.; Kim, H. W.; Shah, R.; Knowles, J. C. Strontium- and Calcium-Containing, Titanium-Stabilised Phosphate-Based Glasses with Prolonged Degradation for Orthopaedic Tissue Engineering. J. Biomater. Appl. 2015, $30,300-310$.

(9) Carta, D.; Pickup, D. M.; Knowles, J. C.; Smith, M. E.; Newport, R. J. Sol-Gel Synthesis of the $\mathrm{P}_{2} \mathrm{O}_{5}-\mathrm{CaO}-\mathrm{Na}_{2} \mathrm{O}-\mathrm{SiO}_{2}$ System as a Novel Bioresorbable Glass. J. Mater. Chem. 2005, 15, 2134-2140.

(10) Carta, D.; Pickup, D. M.; Knowles, J. C.; Ahmed, I.; Smith, M. E.; Newport, R. J. A Structural Study of Sol-Gel and Melt-Quenched Phosphate-Based Glasses. J. Non-Cryst. Solids 2007, 353, 1759-1765.

(11) Carta, D.; Knowles, J. C.; Smith, M. E.; Newport, R. J. Synthesis and Structural Characterization of P2O5-CaO-Na2O SolGel Materials. J. Non-Crystalline Solids 2007, 353, 1141-1149.

(12) Pickup, D. M.; Newport, R. J.; Knowles, J. C. Sol-Gel Phosphate-Based Glass for Drug Delivery Applications. J. Biomater. Appl. 2012, 26 (5), 613-622.

(13) Foroutan, F.; Walters, N. J.; Owens, G. J.; Mordan, N. J.; Kim, H.-W.; de Leeuw, N. H.; Knowles, J. C. Sol-Gel Synthesis of Quaternary $\left(\mathrm{P}_{2} \mathrm{O}_{5}\right)_{55^{-}}(\mathrm{CaO})_{25^{-}}\left(\mathrm{Na}_{2} \mathrm{O}\right)_{(20-\mathrm{x})}-\left(\mathrm{TiO}_{2}\right)_{\mathrm{x}}$ Bioresorbable Glasses for Bone Tissue Engineering Applications $(\mathrm{x}=0,5,10$, or 15). Biomed. Mater. 2015, 10, 045025.

(14) Soulié, J.; Gras, P.; Marsan, O.; Laurencin, D.; Rey, C.; Combes, C. Development of a New Family of Monolithic Calcium (Pyro)Phosphate Glasses by Soft Chemistry. Acta Biomater. 2016, 41, 320-327.

(15) Gras, P.; Rey, C.; Marsan, O.; Sarda, S.; Combes, C. Synthesis and Characterisation of Hydrated Calcium Pyrophosphate Phases of Biological Interest. Eur. J. Inorg. Chem. 2013, 2013 (34), 5886-5895.

(16) Pickup, D. M.; Ahmed, I.; FitzGerald, V.; Moss, R. M.; Wetherall, K. M.; Knowles, J. C.; Smith, M. E.; Newport, R. J. X-Ray Absorption Spectroscopy and High-Energy XRD Study of the Local Environment of Copper in Antibacterial Copper-Releasing Degradable Phosphate Glasses. J. Non-Cryst. Solids 2006, 352 (28-29), 3080-3087.

(17) Mulligan, A. M.; Wilson, M.; Knowles, J. C. The Effect of Increasing Copper Content in Phosphate-Based Glasses on Biofilms of Streptococcus Sanguis. Biomaterials 2003, 24 (10), 1797-1807.

(18) Abou Neel, E. A.; Ahmed, I.; Pratten, J.; Nazhat, S. N.; Knowles, J. C. Characterisation of Antibacterial Copper Releasing Degradable Phosphate Glass Fibres. Biomaterials 2005, 26, 22472254.

(19) Mishra, A.; Petit, L.; Pihl, M.; Andersson, M.; Salminen, T.; Rocherullé, J.; Massera, J. Thermal, Structural and in Vitro Dissolution of Antimicrobial Copper-Doped and Slow Resorbable Iron-Doped Phosphate Glasses. J. Mater. Sci. 2017, 52 (15), 89578972.

(20) Rath, S. N.; Brandl, A.; Hiller, D.; Hoppe, A.; Gbureck, U.; Horch, R. E.; Boccaccini, A. R.; Kneser, U. Bioactive Copper-Doped Glass Scaffolds Can Stimulate Endothelial Cells in Co-Culture in Combination with Mesenchymal Stem Cells. PLoS One 2014, 9 (12), e113319.

(21) Rodriguez, P. J.; Gonzalez, M.; Rios, S. Modulation of the Proliferation and Differentiation of Human Mesenchymal Stem Cells by Copper. J. Cell. Biochem. 2002, 85, 92-100. 
(22) Li, J.; Zhai, D.; Lv, F.; Yu, Q.; Ma, H.; Yin, J.; Yi, Z.; Liu, M.; Chang, J.; Wu, C. Preparation of Copper-Containing Bioactive Glass/ Eggshell Membrane Nanocomposites for Improving Angiogenesis, Antibacterial Activity and Wound Healing. Acta Biomater. 2016, 36, 254-266.

(23) Montanaro, L.; Speziale, P.; Campoccia, D.; Ravaioli, S.; Cangini, I.; Pietrocola, G.; Giannini, S.; Arciola, C. R. Scenery of Staphylococcus Implant Infections in Orthopedics. Future Microbiol. 2011, 6 (11), 1329-1349.

(24) Abou Neel, E. A.; Knowles, J. C. Physical and Biocompatibility Studies of Novel Titanium Dioxide Doped Phosphate-Based Glasses for Bone Tissue Engineering Applications. J. Mater. Sci.: Mater. Med. 2008, 19 (1), 377-386.

(25) Qaysi, M. Al; Petrie, A.; Shah, R.; Knowles, J. C. Degradation of Zinc Containing Phosphate-Based Glass as a Material for Orthopedic Tissue Engineering. J. Mater. Sci.: Mater. Med. 2016, 27 (10), 157.

(26) Salih, V.; Franks, K.; James, M.; Hastings, G. W.; Knowles, J. C.; Olsen, I. Development of Soluble Glasses for Biomedical Use Part II: The Biological Response of Human Osteoblast Cell Lines to Phosphate-Based Soluble Glasses. J. Mater. Sci.: Mater. Med. 2000, 11 (10), 615-620.

(27) Abou Neel, E. A.; Chrzanowski, W.; Pickup, D. M.; O’Dell, L. A.; Mordan, J. N.; Newport, R. J.; Smith, M. E.; Knowles, J. Structure and Properties of Strontium-Doped Phosphate-Based Glasses. J. $R$. Soc., Interface 2009, 6, 435-446.

(28) Ahmed, I.; Parsons, A.; Jones, A.; Walker, G.; Scotchford, C.; Rudd, C. Cytocompatibility and Effect of Increasing MgO Content in a Range of Quaternary Invert Phosphate-Based Glasses. J. Biomater. Appl. 2010, 24 (6), 555-575.

(29) Gough, J. E.; Christian, P.; Scotchford, C. A.; Rudd, C. D.; Jones, I. A. Synthesis, Degradation, and in Vitro Cell Responses of Sodium Phosphate Glasses for Craniofacial Bone Repair. J. Biomed. Mater. Res. 2002, 59, 481-489.

(30) Slater, C.; Laurencin, D.; Burnell, V.; Smith, M. E.; Grover, L. M.; Hriljac, J. A.; Wright, A. J. Enhanced Stability and Local Structure in Biologically Relevant Amorphous Materials Containing Pyrophosphate. J. Mater. Chem. 2011, 21 (46), 18783-18791.

(31) Massiot, D.; Fayon, F.; Capron, M.; King, I.; Le Calvé, S.; Alonso, B.; Durand, J.-O.; Bujoli, B.; Gan, Z.; Hoatson, G. Modelling One- and Two-Dimensional Solid-State NMR Spectra. Magn. Reson. Chem. 2002, 40 (1), 70-76.

(32) Gutierrez, J.; Barry-Ryan, C.; Bourke, P. Antimicrobial Activity of Plant Essential Oils Using Food Model Media: Efficacy, Synergistic Potential and Interactions with Food Components. Food Microbiol. 2009, 26 (2), 142-150.

(33) Stedman, A.; Maluquer De Motes, C.; Lesellier, S.; Dalley, D.; Chambers, M.; Gutierrez-Merino, J. Lactic Acid Bacteria Isolated from European Badgers (Meles Meles) Reduce the Viability and Survival of Bacillus Calmette-Guerin (BCG) Vaccine and Influence the Immune Response to BCG in a Human Macrophage Model. BMC Microbiol. 2018, 18 (1), 7.

(34) Eliaz, N.; Metoki, N. Calcium Phosphate Bioceramics: A Review of Their History, Structure, Properties, Coating Technologies and Biomedical Applications. Materials 2017, 10 (4), 334.

(35) Navarro, M.; Del Valle, S.; Martínez, S.; Zeppetelli, S.; Ambrosio, L.; Planell, J. A.; Ginebra, M. P. New Macroporous Calcium Phosphate Glass Ceramic for Guided Bone Regeneration. Biomaterials 2004, 25, 4233-4241.

(36) Abrahams, I.; Franks, K.; Hawkes, G. E.; Philippou, G.; Knowles, J.; Nunes, T. ${ }^{23} \mathrm{Na},{ }^{27} \mathrm{Al}$ and ${ }^{31} \mathrm{P}$ NMR and X-Ray Powder Diffraction Study of $\mathrm{Na} / \mathrm{Ca} / \mathrm{Al}$ Phosphate Glasses and Ceramics. J. Mater. Chem. 1997, 7 (23), 1573-1580.

(37) Gras, P.; Baker, A.; Combes, C.; Rey, C.; Sarda, S.; Wright, A. J.; Smith, M. E.; Hanna, J. V.; Gervais, C.; Laurencin, D.; et al. From Crystalline to Amorphous Calcium Pyrophosphates: A Solid State Nuclear Magnetic Resonance Perspective. Acta Biomater. 2016, 31, 348-357.
(38) Brow, R. K.; Tallant, D. R.; Myers, S. T.; Phifer, C. C. The Short-Range Structure of Zinc Polyphosphate Glass. J. Non-Cryst. Solids 1995, 191 (5), 45-55.

(39) Pemberton, J. E.; Latifzadeh, L.; Fletcher, J. P.; Risbud, S. H. Raman Spectroscopy of Calcium Phosphate Glasses with Varying $\mathrm{CaO}$ Modifier Concentrations. Chem. Mater. 1991, 3 (13), 195-200.

(40) Lai, Y. M.; Liang, X. F.; Yang, S. Y.; Wang, J. X.; Cao, L. H.; Dai, B. Raman and FTIR Spectra of Iron Phosphate Glasses Containing Cerium. J. Mol. Struct. 2011, 992 (1-3), 84-88.

(41) Stoch, P.; Szczerba, W.; Bodnar, W.; Ciecinska, M.; Stoch, A.; Burkel, E. Structural Properties of Iron-Phosphate Glasses: Spectroscopic Studies and Ab Initio Simulations. Phys. Chem. Chem. Phys. 2014, 16, 19917-19927.

(42) Valappil, S. P.; Ready, D.; Abou Neel, E. A.; Pickup, D. M.; Chrzanowski, W.; O’Dell, L. A.; Newport, R. J.; Smith, M. E.; Wilson, M.; Knowles, J. C. Antimicrobial Gallium-Doped Phosphate-Based Glasses. Adv. Funct. Mater. 2008, 18 (5), 732-741.

(43) Begum, S.; Johnson, W. E.; Worthington, T.; Martin, R. A. The Influence of $\mathrm{PH}$ and Fluid Dynamics on the Antibacterial Efficacy of 45S5 Bioglass. Biomed. Mater. 2016, 11 (1), No. 015006.

(44) Rana, K. S.; De Souza, L. P.; Isaacs, M. A.; Raja, F. N. S.; Morrell, A. P.; Martin, R. A. Development and Characterization of Gallium-Doped Bioactive Glasses for Potential Bone Cancer Applications. ACS Biomater. Sci. Eng. 2017, 3 (12), 3425-3432.

(45) Rodan, S. B.; Imai, Y.; Thiede, M. A.; Wesolowski, G.; Thompson, D.; Bar-shavit, Z.; Shull, S.; Mann, K.; Rodan, G. A. Characterization of a Human Osteosarcoma Cell Line (Saos-2) with Osteoblastic Properties. Cancer Res. 1987, 47, 4961-4966.

(46) Pickup, D. M.; Guerry, P.; Moss, R. M.; Knowles, J. C.; Smith, M. E.; Newport, R. J. New Sol-Gel Synthesis of a $(\mathrm{CaO})_{0.3}\left(\mathrm{Na}_{2} \mathrm{O}\right)_{0.2}\left(\mathrm{P}_{2} \mathrm{O}_{5}\right)_{0.5}$ Bioresorbable Glass and Its Structural Characterisation. J. Mater. Chem. 2007, 17 (45), 4777-4784.

(47) Raja, F. N. S.; Worthington, T.; Isaacs, M. A.; Rana, K. S.; Martin, R. A. The Antimicrobial Efficacy of Zinc Doped PhosphateBased Glass for Treating Catheter Associated Urinary Tract Infections. Mater. Sci. Eng., C 2019, 103, 109868.

(48) Gerard, C.; Bordeleau, L.-J.; Barralet, J.; Doillon, C. J. The Stimulation of Angiogenesis and Collagen Deposition by Copper. Biomaterials 2010, 31, 824-831.

\section{NOTE ADDED AFTER ASAP PUBLICATION}

This paper was published ASAP on October 25, 2019, with a version of Figure 7 that lacked a legend and some information missing in the caption to Figure 10. The corrected version was reposted on October 30, 2019. 